\title{
Effect of measles-virus infection and interferon treatment on invasiveness of Shigella flexneri in HEp2-cell cultures
}

\author{
G. BUKHOLM, ${ }^{*}$ KRISTIN MODALSLI and M. DEGRÉ
}

\begin{abstract}
Department of Virology, National Institute of Public Health and *Microbiological Laboratory, Ullevål Hospital, Oslo, Norway
\end{abstract}

\begin{abstract}
Summary. The influence of measles-virus infection on the invasiveness of Shigella flexneri in HEp2-cell cultures was studied. Bacterial invasiveness was significantly enhanced in cell cultures incubated with virus before bacterial inoculation. This effect was a function of time after introduction of virus to the cell cultures and of the concentration of virus. The increase in bacterial invasiveness was observed before production of infectious virus particles and before a cytopathic effect was evident. A similar enhancement of invasiveness was demonstrated when cell cultures were pretreated with UV-inactivated measles virus. Pretreatment of cells with interferon did not influence invasiveness, although it reduced the effect of measles-virus infection.
\end{abstract}

\section{Introduction}

Several groups of investigators have reported a high correlation between invasive properties of bacteria in vitro and the ability to produce disease in man for Salmonella spp. (Gianella et al., 1973; Bukholm and Lassen, 1982), Shigella spp. (Gerber and Watkins, 1961; LaBrec et al., 1964; Formal et al., 1971; Hale and Bonventre, 1979) and enteroinvasive Escherichia coli (DuPont et al., 1971; Mehlman et al., 1977). The in-vitro invasiveness seems to be associated with the presence of high mol.-wt plasmids for all these species (Sansonetti et al., 1981 and 1983; Harris et al., 1982; Jones et al., 1982).

In previous studies we have shown that preinfection of HEp2-cell cultures with coxsackie B1 virus enhances the invasiveness of $S$. typhimurium in cell cultures (Bukholm and Degré, 1984). The effect seemed to be specific and not due to nonspecific damage to the cell membrane because two strains of non-enteropathogenic $E$. coli were noninvasive in cell cultures even late in the virusmultiplication cycle. The enhancement of invasiveness was evident early in the virus-multiplication cycle, even before a virus-dependent cytopathic effect (CPE) on the cell cultures was observed. It was further shown that within the first $3 \mathrm{~h}$ of virus infection a similar enhancement of invasiveness was achieved with UV-inactivated virus particles (Bukholm et al., 1985). To examine whether this

Received 19 Dec. 1985; revised version accepted 31 Mar. 1986. interaction between bacteria and viruses in cell cultures is a general phenomenon or specific for coxsackie virus and salmonellae, we have established a new model with Sh. flexneri and an RNA virus with replication and metabolic effects on cell cultures different from those of enteroviruses.

\section{Materials and methods}

\section{Bacterium}

The strain of Sh. flexneri used was SIFF S662/81, originally isolated from a patient with gastro-enteritis and found to be invasive in HEp2-cell monolayers in previous studies (Bukholm and Lassen, 1982).

\section{Cells}

Monolayers of HEp2 cells were grown on glass coverslips (14-mm diameter) in 24-well tissue-culture plates (Linbro). Each well received $1 \mathrm{ml}$ of cell suspension, c. $1 \times 10^{5}$ cells, in Eagle's Basal Medium (BME) containing bicarbonate, fetal bovine serum (FBS) $10 \%$, and streptomycin and penicillin $(100 \mu \mathrm{g} / \mathrm{ml})$. The cells were incubated for $48 \mathrm{~h}$ at $37^{\circ} \mathrm{C}$ in an atmosphere of $\mathrm{CO}_{2} 5 \%$ with $100 \%$ relative humidity. The cell cultures were suitable for inoculation when they formed an almost continuous monolayer with intermediate blank areas (leopard spots). Before inoculation they were washed three times with $0.15 \mathrm{M}$ phosphate-buffered saline (PBS) at $37^{\circ} \mathrm{C}$, incubated for $1 \mathrm{~h}$ in $\mathrm{BME}$ without antibiotics and then washed three more times with PBS to reduce 
the concentration of antibiotics. Cells finally received $1 \mathrm{ml}$ of fresh BME containing FBS 1\% without antibiotics.

\section{Virus}

Measles virus, Edmondson strain, was grown in HEp2-cell-culture monolayers. When the CPE was well developed, the cell cultures were frozen and thawed, and the supernate was stored at $-20 \mathrm{C}$. Infectivity titration was performed in HEp2 cells in Nunclon 96-well tissueculture plates, six parallel rows for each dilution. The concentration of virus in the suspension was $10^{6.3}$ TCID $50 / \mathrm{ml}$ according to the Reed and Muench equation.

\section{UV-inactivation of virus}

Two $\mathrm{ml}$ of measles-virus suspension, containing $10^{6.3}$ TCID $50 / \mathrm{ml}$, were poured into a petri-dish $(50-\mathrm{mm}$ diameter) and inactivated by UV irradiation from a UV lamp $\left(0.67 \mathrm{~mW} \mathrm{~cm}^{2}\right)$ for $80 \mathrm{~s}$ at a distance of $120 \mathrm{~mm}$. After inactivation, infectivity was reduced to $<1$ TCID $50 / \mathrm{ml}$.

\section{Interferons and anti-interferon globulin}

Partially purified human-leukocyte interferon $(2 \times$ $10^{6} \mathrm{U} / \mathrm{mg}$ of protein) was received from Dr K. Cantell, Helsinki, and partially purified human $\gamma$ interferon ( $10^{5.5} \mathrm{U} / \mathrm{mg}$ of protein) from Dr J. Georgiades, ImmunoModulators Laboratory, Houston, TX, USA. Interferons were assayed by an infectivity-inhibition microtest as described by Dahl and Degré (1972). Anti-human interferon globulin was obtained from $\mathrm{Dr} J$. K. Dunnick, Bethesda. MD, USA.

\section{Test for invasive properties of bacteria}

Cell cultures were seeded with various concentrations of non-inactivated and UV-inactivated virus. After incubation with the virus for various periods, the cultures were inoculated with $200 \mu \mathrm{l}$ of a bacterial suspension that had been cultured on heart-infusion agar and suspended in PBS. The concentration was adjusted to an optical density of 1.0 at $320 \mathrm{~nm}$ (Hitachi model 101 spectrophotometer). Control cell cultures without virus were inoculated with bacteria at the same time. After inoculation, cell cultures were incubated for $3 \mathrm{~h}$ at $37 \mathrm{C}$ in an atmosphere of $\mathrm{CO}_{2} 5 \%$. The cell cultures were then washed three times with PBS at $37^{\circ} \mathrm{C}$ to reduce the cytotoxic effect of bacteria on cell cultures, incubated for another $2 \mathrm{~h}$ and finally washed three times with PBS to remove non-attached bacteria.

The cultures were fixed overnight in glutaraldehyde $2 \%$ in $0.1 \mathrm{M}$ cacodylate buffer with $0.1 \mathrm{M}$ sucrose, $p \mathrm{H} 7.2$. After fixation, the cultures were washed three times in the same buffer to remove glutaraldehyde. The specimens were stained for $5 \mathrm{~min}$ with acridine orange $50 \mathrm{mg} /$ $\mathrm{L}$ (Bukholm et al., 1982) in cacodylate buffer, then washed three times in the buffer and mounted on glass slides with a drop of immersion oil for microscopy.

The cell cultures were examined by a combined lightoptical method described in detail previously (Bukholm et al., 1982). The method, a combination of differential interference-contrast microscopy and UV incident-light microscopy, differentiates clearly between extra- and intra-cellular locations of bacteria.

The intracellular and extracellular locations of bacteria were recorded with the microscope fitted with a planachromate objective lens (magnification $\times 100$ and an aperture of 1.25). Counting was performed at a magnification of 1000 . Cells $(200)$ in each of three parallels were counted and the number of intracellular bacteria/ cell recorded.

\section{Statistical method}

The frequency distributions of cells with adhesive or intracellular bacteria were made for each experiment. Statistical differences between the distributions were evaluated by means of the Pearson $\chi^{2}$ test. Significant differences were calculated at the $p<0.01$ level. In tables I-III, the mean values of the frequency distributions are presented.

\section{Results}

Adhesiveness and invasiveness of Sh. flexneri in HEp2-cell cultures

When Sh. flexneri suspensions were added to cell cultures, some bacteria attached to the cells. Adherence could be observed after incubation for $1 \mathrm{~h}$. Thereafter, the proportion of cells with adherent bacteria and the number of bacteria/cell increased slowly with further incubation. Incubation of cells with bacteria for more than $3 \mathrm{~h}$ resulted in a gradual deterioration of the HEp2 cultures. Invasive bacteria were not observed within $3 \mathrm{~h}$ of inoculation. To achieve a higher degree of invasiveness, bacteria-containing medium was removed after $3 \mathrm{~h}$, the cells were washed and incubated for another $2 \mathrm{~h}$ in fresh medium. At that time, $3-6 \%$ of the cells were invaded by bacteria.

Effect of measles virus on invasiveness and adhesiveness of Sh. flexneri in HEp2-cell cultures

When 2-day-old HEp2-cell cultures were incubated with either 10 or 100 TCID50 of measles virus, infectious virus could be demonstrated after incubation for $12 \mathrm{~h}$. The titres of extracellular virus gradually increased during the following 3 days.

Sh. flexneri cultures were added to the measles virus-infected cell cultures after various periods of preincubation with virus, from $30 \mathrm{~min}$ to $96 \mathrm{~h}$, and 
Table I. Adhesiveness and invasiveness of Sh. flexneri in HEp2 cells after various incubation periods with measles virus

\begin{tabular}{|c|c|c|c|c|c|}
\hline \multirow{2}{*}{$\begin{array}{l}\text { Incubation } \\
\text { time with } \\
\text { virus* } \\
\text { (h) }\end{array}$} & \multicolumn{2}{|c|}{$\begin{array}{l}\text { Numbert of HEp2 cells } \\
\text { with bacteria which were }\end{array}$} & \multicolumn{2}{|c|}{$\begin{array}{c}\text { Number } \dagger \text { of bacteria/ } \\
200 \text { HEp } 2 \text { cells } \\
\text { that were }\end{array}$} & \multirow{2}{*}{$\begin{array}{c}\text { Number of } \\
\text { invasive bacteria/ } \\
\text { invaded } \\
\text { HEp } 2 \text { cell }\end{array}$} \\
\hline & adhesive & invasive & adhesive & invasive & \\
\hline \multicolumn{6}{|l|}{ (a) } \\
\hline 0 & $31 \pm 1 \cdot 3$ & $8 \pm 0.3$ & $120 \pm 1 \cdot 3$ & $21 \pm 2.3$ & $2 \cdot 6$ \\
\hline 0.5 & $28 \pm 2 \cdot 5$ & $10 \pm 1 \cdot 3$ & $136 \pm 2 \cdot 6$ & $37 \pm 1 \cdot 2$ & $3 \cdot 7$ \\
\hline 1 & $34 \pm 1 \cdot 9$ & $14 \pm 0 \cdot 8$ & $112 \pm 3 \cdot 7$ & $46 \pm 2 \cdot 0$ & $3 \cdot 3$ \\
\hline 2 & $32 \pm 2 \cdot 6$ & $19 \pm 1 \cdot 7$ & $109 \pm 3 \cdot 4$ & $78 \pm 1 \cdot 6$ & $4 \cdot 1$ \\
\hline 4 & $31 \pm 1 \cdot 3$ & $24 \pm 0.9$ & $129 \pm 1 \cdot 4$ & $99 \pm 1 \cdot 0$ & $4 \cdot 1$ \\
\hline 6 & $38 \pm 2 \cdot 2$ & $29 \pm 1.7$ & $136 \pm 2 \cdot 7$ & $116 \pm 2 \cdot 3$ & $4 \cdot 0$ \\
\hline 24 & $35 \pm 0.9$ & $32 \pm 2 \cdot 4$ & $124 \pm 2 \cdot 1$ & $122 \pm 1 \cdot 9$ & $3 \cdot 8$ \\
\hline 48 & $31 \pm 1 \cdot 0$ & $34 \pm 0.9$ & $109 \pm 2.9$ & $143 \pm 2 \cdot 7$ & $4 \cdot 2$ \\
\hline \multicolumn{6}{|l|}{ (b) } \\
\hline 0 & $31 \pm 2 \cdot 7$ & $9 \pm 0.6$ & $123 \pm 2 \cdot 9$ & $19 \pm 1.4$ & $2 \cdot 1$ \\
\hline 0.5 & $28 \pm 1 \cdot 7$ & $10 \pm 0 \cdot 3$ & $106 \pm 3 \cdot 0$ & $25 \pm 2 \cdot 3$ & $2 \cdot 5$ \\
\hline 1 & $27 \pm 2 \cdot 0$ & $12 \pm 0 \cdot 7$ & $102 \pm 2 \cdot 7$ & $33 \pm 2 \cdot 0$ & $2 \cdot 8$ \\
\hline 2 & $32 \pm 1.9$ & $15 \pm 1 \cdot 0$ & $131 \pm 1 \cdot 3$ & $53 \pm 2 \cdot 7$ & 3.5 \\
\hline 4 & $31 \pm 2 \cdot 5$ & $18 \pm 2 \cdot 0$ & $135 \pm 3 \cdot 4$ & $61 \pm 2 \cdot 5$ & $3 \cdot 4$ \\
\hline 6 & $31 \pm 2 \cdot 7$ & $24 \pm 1 \cdot 2$ & $135 \pm 3.4$ & $83 \pm 2 \cdot 7$ & $3 \cdot 5$ \\
\hline 24 & $26 \pm 2 \cdot 2$ & $28 \pm 1 \cdot 0$ & $102 \pm 2 \cdot 3$ & $94 \pm 2 \cdot 9$ & $3 \cdot 4$ \\
\hline 48 & $29 \pm 2 \cdot 0$ & $30 \pm 2 \cdot 4$ & $117 \pm 2 \cdot 5$ & $105 \pm 3 \cdot 1$ & $3 \cdot 5$ \\
\hline
\end{tabular}

* The measles virus TCID50/ml was: $a, 10 ; b, 100$.

$\dagger$ Mean \pm standard deviation.

the numbers of intracellularly and extracellularly located bacteria were recorded. The number of extracellular, adherent bacteria was not significantly altered during the course of virus infection. The proportion of cells with adherent bacteria and the number of adherent bacteria/cell remained at a constant level in all cultures tested. On the other hand, invasiveness was significantly enhanced during the virus infection (table I). The proportion of infected cells and the number of intracellular bacteria/infected cell increased gradually from $1 \mathrm{~h}$ of virus pre-incubation and reached a peak at $48 \mathrm{~h}$. The effect was more pronounced in cultures incubated with the higher concentration of virus (table I).

Effect of treatment of cells with UV-inactivated measles virus on adhesiveness and invasiveness of $S h$. flexneri in HEp2 cells

Because of the low multiplicity of the virus infection in the above described experiment, only a very small proportion of the cells received infectious virus particles. Nevertheless, the virus treatment influenced bacterial invasiveness within a short time of incubation, to a much higher extent than might be explained by the infectious process alone. It is known, however, that a large proportion of non-infectious particles are present in all virus preparations. Thus, in the following experiments the possible influence of non-infectious, UV-inactivated measles-virus particles on bacterial invasiveness was tested. Less than one infectious virus particle $/ \mathrm{ml}$ was present after UV-inactivation. The number of bacteria/infected cell and the proportion of infected cells increased in the cultures that were treated with UV-inactivated virus. The effect of UV-inactivated virus preparation was comparable to that of infectious control virus. Results are presented in table II.

Effect of interferon on the interaction between Sh. flexneri and measles in HEp2-cell cultures

Treatment of HEp2 cells with human-leukocyte or human $\gamma$ interferon in concentrations from 1 to $1000 \mathrm{U} / \mathrm{ml}$ for $24 \mathrm{~h}$ did not influence the adhesiveness or invasiveness of Sh. flexneri. Treatment of cells with interferon $24 \mathrm{~h}$ before measles-virus infection reduced development of virus infection and the virus-induced enhancement of bacterial invasiveness. However, the observed dose-response curves of these effects were different. Whilst the effect on viral multiplication was almost linear, the effect on bacterial invasiveness was greatest at $100 \mathrm{U} / \mathrm{ml}$ (figure). This treatment almost completely eliminated the effect produced by the virus infection (table III). 
Table II. Adhesiveness and invasiveness of Sh. flexneri in HEp2 cells after incubation for $24 \mathrm{~h}$ with infectious or non-infectious measles virus

\begin{tabular}{|c|c|c|c|c|c|}
\hline \multirow{2}{*}{$\begin{array}{l}\text { Incubation } \\
\text { with virus* } \\
\text { that was }\end{array}$} & \multicolumn{2}{|c|}{$\begin{array}{l}\text { Numbert of HEp2 cells } \\
\text { with bacteria that were }\end{array}$} & \multicolumn{2}{|c|}{$\begin{array}{l}\text { Numbert of bacteria/ } \\
200 \text { HEp } 2 \text { cells } \\
\text { that were }\end{array}$} & \multirow{2}{*}{$\begin{array}{l}\text { Number of } \\
\text { invasive bacteria/ } \\
\text { invaded } \\
\text { HEp2 cell }\end{array}$} \\
\hline & adhesive & invasive & adhesive & invasive & \\
\hline \multicolumn{6}{|l|}{ (a) } \\
\hline Infectious & $30 \pm 1 \cdot 9$ & $33 \pm 2 \cdot 2$ & $110 \pm 3 \cdot 1$ & $116 \pm 1 \cdot 4$ & 3.5 \\
\hline Non-infectious.+ & $35 \pm 2 \cdot 7$ & $32 \pm 2 \cdot 5$ & $124 \pm 2 \cdot 7$ & $107 \pm 1 \cdot 6$ & $3 \cdot 3$ \\
\hline \multicolumn{6}{|l|}{ (b) } \\
\hline Infectious & $29 \pm 2 \cdot 4$ & $25 \pm 1 \cdot 7$ & $128 \pm 2 \cdot 4$ & $96 \pm 1.9$ & 3.8 \\
\hline Non-infectious + & $34 \pm 2 \cdot 6$ & $27 \pm 1.9$ & $116 \pm 1.9$ & $103 \pm 2 \cdot 2$ & 3.8 \\
\hline No virus, control & $31 \pm 1 \cdot 8$ & $8 \pm 0.9$ & $120 \pm 2 \cdot 3$ & $23 \pm 1 \cdot 5$ & 2.9 \\
\hline
\end{tabular}

* The measles virus TCID $50 \mathrm{ml}$ (in + . before UV inactivation) was : $a, 100: b, 10$.

+ Mean \pm standard deviation.
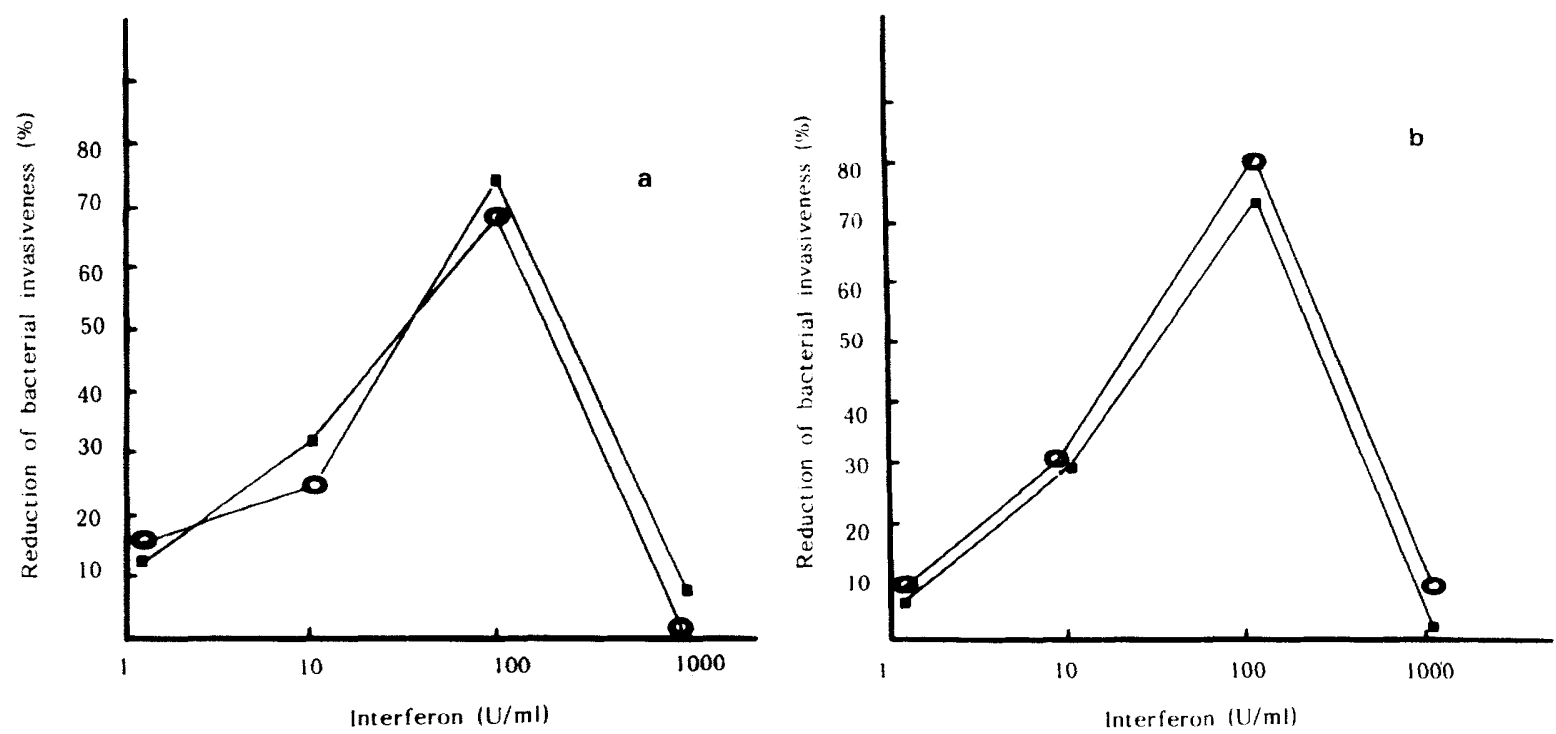

Figure. Reduction of invasiveness of Sh. flexneri for HEp2 cells treated with human interferon before incubation with measles virus (TCID50 ml. 100): (a), human leukocyte interferon; (b), human $;$ interferon; $\bigcirc-O$, cell count (HEp2 cells with intracellular bacteria); - bacterial count (intracellular bacteria infected HEp2 cell).

\section{Discussion}

Combined infections with viruses and bacteria often produce more severe disease than either agent alone. When an organism is first infected with a virus, several anti-bacterial factors may be modified, including immune response and phagocytosis (Degré and Glasgow, 1968; Degré, 1970 and 1971; Howard and Narajan, 1974; Howard et al., 1974; Jakab et al.. 1980). The direct interaction between bacteria and cells may also be influenced. Thus, adherence of Staphylococcus aureus to cells was enhanced by infection of the cells with influenza A virus (Davison and Sandford, 1981). In a previous study, we reported an additional mechanism whereby a virus might alter the host resistance to bacterial infection; invasiveness of $S$. typhimurium for cells was enhanced by coxsackie B virus infection. A significant effect was observed when one infectious virus particle/100 HEp2 cells was added to the cultures and incubated for 3-5 h (Bukholm and Degré, 1984). It was also shown that infection of HEp2-cell cultures with UV-inactivated coxsackie B virus enhanced the invasiveness of $S$. 
Table III. Invasiveness of Sh. flexneri in HEp2-cell cultures treated with human-leukocyte interferon and measles virus

\begin{tabular}{|c|c|c|c|}
\hline \multirow[b]{2}{*}{$\begin{array}{l}\text { Titre of } \\
\text { interferon }\end{array}$} & \multirow{2}{*}{$\begin{array}{l}\text { Percentage } \\
\text { of HEp } 2 \text { cells } \\
\text { infected }\end{array}$} & \multicolumn{2}{|c|}{$\begin{array}{c}\text { Number of } \\
\text { intracellular bacteria/ }\end{array}$} \\
\hline & & $\begin{array}{l}\text { infected } \\
\text { HEp2 cell }\end{array}$ & $\begin{array}{l}200 \text { HEp2 } \\
\text { cells }\end{array}$ \\
\hline Control* & 4 & $3 \cdot 3$ & 23 \\
\hline $0 \dagger$ & 16 & $3 \cdot 7$ & 119 \\
\hline 1 & 15 & $3 \cdot 7$ & 108 \\
\hline 10 & 12 & $3 \cdot 7$ & 84 \\
\hline 100 & 4 & $4 \cdot 6$ & 32 \\
\hline 500 & 11 & $3 \cdot 7$ & 82 \\
\hline 1000 & 15 & $3 \cdot 7$ & 111 \\
\hline
\end{tabular}

* Control cells, not treated with either measles virus or interferon.

$\dagger$ In the other experiments, cells were treated for $24 \mathrm{~h}$ with interferon (at stated titre) before incubation with measles virus (TCID50/ml, 100).

typhimurium (Bukholm et al., 1985). When cells were treated with UV-irradiated virus preparations containing $10 \mathrm{TCID} 50 / \mathrm{ml}$ for 3 or $4 \mathrm{~h}$, the effect was comparable to that achieved by addition of preparations containing $1.0 \times 10^{7} \mathrm{TCID} 50 / \mathrm{ml}$. The number of virus particles in the two preparations was the same, but the number of infectious particles was reduced by a factor of $10^{6}$ indicating that the effect of virus on invasiveness of $S$. typhimurium did not depend on the presence of infectious virus in the early phase of virus infection.

In this study we have shown that this type of interaction in vitro can also be observed in a model with a different invasive bacterium and a virus with properties quite different from those of enteroviruses. The invasiveness of Sh. flexneri was considerably enhanced in cell cultures infected with measles virus. As with enterovirus, the enhancement could also be achieved by UV-inactivated measles-virus particles.

The enhancement of bacterial invasiveness was evident before a cytopathic effect in the cell cultures was recorded when non-inactivated virus was used, supporting the view that the virus effect is specific and not due to nonspecific deterioration of cellular resistance to bacterial invasiveness. The fact that a similar enhancement of invasiveness was achieved with non-inactivated particles is in agreement with that argument.

Both the invasiveness-promoting effect and the cytopathic effect of measles virus were prevented by interferon treatment of the cells. Earlier experiments have shown that interferons can inhibit the invasiveness of Salmonella species in HEp2-cell cul- tures (Bukholm and Degré, 1983 and 1985; Bukholm et al., 1984). We have not, however, been able to record any direct effect of interferon on invasiveness of Sh. flexneri strain SIFF 662/81 in HEp2 cells. Thus, we assume that the inhibition of bacterial invasiveness in cells infected with virus must be due to an effect initiated by virus infection and not to a direct effect on bacterial penetration of the cell membrane. The anti-invasive effect follows a biphasic curve with maximum activity at $100 \mathrm{U} / \mathrm{ml}$; again, a higher titre of interferon $(1000 \mathrm{U} / \mathrm{ml})$ had a less pronounced effect. This biphasic curve is typical for several non-antiviral activities of interferon (Braun and Levy, 1972; Strannegård et al., 1978; Rollag and Degré, 1981) including effects on the invasiveness of Salmonella spp. (Bukholm and Degré, 1983, 1984 and 1985).

The mechanisms of bacterial invasion are not known. Earlier studies by Jones et al. (1981) have shown that bacterial invasion in cell cultures may be divided into three phases: reversible adhesion, irreversible adhesion and invasion, each influenced by virus infection. One possibility is a change of electrical potential in the medium or the solution surrounding the cells. An increase in the number of particles in the solution might decrease the $\xi$ potential thereby increasing the probability of contact between bacteria and host cells.

However, several experiments have shown that the endocytosis apparatus of the host cell is important for the invasive process of Shigella and Salmonella species. Bacterial invasiveness is blocked in cells treated with cytochalasins (Hale et al., 1979; Bukholm, 1984). It is well known that the measles virus produces a polypeptide of mol. wt 40000 associated with cell fusion and haemagglutinating activities (Tyrrell and Norrby, 1978). Fusion of HEp2 cells infected with measles virus is reported to occur 20-30 h after infection (Graves et al., 1978). Whether this fusion polypeptide is associated with increased invasiveness of bacteria is still unclear, and the problem is under investigation in our laboratory.

If the virus infection does have any effect upon the state of irreversible adhesion, an effect on cellular receptor function should be anticipated. However, our experiments did not yield results pointing to an effect at that level. On the other hand, bacterial invasiveness in cell cultures is known to depend on the presence of a high mol.-wt plasmid for $S h$. flexneri (Sansonetti et al., 1983). Removal of the plasmid decreased bacterial adhesiveness and invasiveness in cell cultures. The plasmid associated with invasiveness in vitro probably codes for polypeptide receptors modifying the bacterial surface 
(Sansonetti et al., 1983). These receptors might induce endocytosis of invasive organisms by sequential binding to determinants on HEp2, HeLa or intestinal epithelial cells. The effect of virus on the expression of such receptors is not known.

The results presented show that infection of cell

\section{REFERENCES}

Braun W. Levy H B 1972 Interferon preparations as modifiers of immune responses. Proceedings of the Society for Experimental Biology and Medicine 141:769 773.

Bukholm G 1984 Effect of cytochalasin B and di-hydrocytochalasin $B$ on invasiveness of enteroinvasive bacteria in HEp-2 cell cultures. Acta Pathologica Microbiologica et Immunologica Scandinavica B 92:145 149.

Bukholm G. Degré M 1983 Effect of human leukocyte interferon on invasiveness of Salmonella species in HEp-2 cell cultures. Infection and Immunity 42:1198-1202.

Bukholm G. Degré M 1984 Invasiveness of Salmonella typhimurium in HEp-2 cell cultures preinfected with coxsackie Bl virus. Acta Pathologica Microbiologica et Immunologica Scandinavica B 92:45-51.

Bukholm G. Degré M 1985 Effect of human gamma interferon on invasiveness of Saimonella typhimurium in HEp-2 cell cultures. Journal of Interferon Research 5:45-53.

Bukholm G. Lassen J 1982 Bacterial adhesiveness in cell culture monolayer. 2. In-vitro invasiveness of 45 strains belonging to the family Enterobacteriaceae. Acta Pathologica Microbiologica et Immunologica Scandinavica B 90:409-413.

Bukholm G. Berdal B P. Haug C. Degré M 1984 Mouse fibroblast interferon modifies Salmonella typhimurium infection in infant mice. Infection and Immunity 45:62-66.

Bukholm G. Holberg-Petersen M. Degré M 1985 Invasiveness of Salmonella typhimurium in HEp-2 cell cultures pretreated with UV-inactivated coxsackie virus. Acta Pathologica Microbiologica et Immunologica Scandinavica B 93: $61-65$

Bukholm G, Johansen B V. Namork E, Lassen J 1982 Bacterial adhesiveness and invasiveness in cell culture monolayer. 1. A new combined light optical method evaluated by scanning electron microscopy. Acta Pathologica Microbiologica et Immunologica Scandinavica B 90:403-408.

Dahl H. Degré M 1972 A micro assay for mouse and human interferon. Acta Pathologica et Microbiologica Scandinavica $\mathrm{B}$ 80:863-870.

Davison V E. Sanford B A 1981 Adherence of Staphylococcus aureus to influenza A virus-infected Madin-Darby canine kidney cell cultures. Infection and Immunity 32:118-126. 1981.

Degre M 1970 Synergistic effect in viral-bacterial infection. 2. Influence of viral infection on the phagocytic ability of alveolar macropghages. Acta Pathologica et Microbiologica Scandinavica B 78:41-50.

Degré $M$ 1971 Synergistic effect in viral-bacterial infection. 5. Functional studies on the role of the ciliary activity in the mouse trachea. Acta Pathologica et Microbiologica Scandinavica $\mathrm{B} 79: 137-141$.

Degré M. Glasgow L A 1968 Synergistic effect in viral-bacterial infection. 1. Combined infection of the respiratory tract in mice with parainfluenza virus and Haemophilus influenzae. Journal of Infectious Diseases 118:449-462. cultures with virus makes the cell more susceptible to a secondary bacterial invasion. The effect of measles virus can be achieved with infectious virus particles as well as with non-infectious particles, and the effect can be abolished in cells pretreated with interferons.

DuPont H L, Formal S B, Hornick R B, Snyder M J, Libonati J P. Sheahan D G, LaBrec E H, Kalas J P 1971 Pathogenesis of Escherichia coli diarrhea. New England Journal of Medicine 285: $1-9$.

Formal S B. DuPont H L, Hornick R, Snyder M J, Libonati J, LaBrec E H 1971 Experimental models in the investigation of the virulence of dysentery bacilli and Escherichia cali. Annals of the New York Academy of Sciences 176:190-196.

Gerber D F. Watkins H M S 1961 Growth of shigellae in monolayer tissue cultures. Journal of Bacteriology 82:815-822.

Gianella R A, Washington O, Gemski P, Formal S B 1973 Invasion of HeLa cells by Salmonella typhimurium: a model for study of invasiveness of Salmonella. Journal of Infectious Diseases 128:69-75.

Graves M C, Silver S M, Choppin P W 1978 Measles virus polypeptide synthesis in infected cells. Virology 86:254-263.

Hale T L, Bonventre P F 1979 Shigella infection of Henle intestinal epithelial cells: role of the bacterium. Infection and Immunity 24:879-886.

Hale T L, Morris R E, Bonventre P F 1979 Shigella infection of Henle intestinal epithelial cells: role of the host cell. Infection and Immunity 24:887-894.

Harris J R, Wachsmuth I K, Davis B R, Cohen M L 1982 Highmolecular-weight plasmid correlates with Escherichia coli enteroinvasiveness. Infection and Immunity 37:1295-1298.

Howard R J, Najaran J S 1974 Cytomegalovirus-induced immune suppression. I. Humoral immunity. Clinical and Experimental Immunology 18:109-118.

Howard R J. Miller J, Najaran J S 1974 Cytomegalovirusinduced immune suppression. II. Cell-mediated immunity. Clinical and Experimental Immunology 18:118-126.

Jakab G J, Warr G A, Sannes P L 1980 Alveolar macrophage ingestion and phagosome-lyosome fusion defect associated with virus pneumonia. Infection and Immunity 27:960-968.

Jones G W. Rabert D K, Svinarich D M, Whitfield H J 1982 Association of adhesive, invasive and virulent phenotypes of Salmonella typhimurium with autonomous 60-megadalton plasmids. Infection and Immunity 38:476-486.

Jones G W, Richardson L A, Uhlman D 1981 The invasion of HeLa cells by Salmonella typhimurium: reversible and irreversible bacterial attachment and the role of bacterial motility. Journal of General Microbiology 127:351 -360.

LaBrec E H, Schneider H, Magnani T J, Formal S B 1964 Epithelial cell penetration as an essential step in the pathogenesis of bacillary dysentery. Journal of Bacteriology 88: $1503-1518$

Mehlman I J, Eide E L, Sanders A C, Fishbein M, Aulisio C CG 1977 Methodology for recognition of invasive potential of Escherichia coli. Journal of the Association of Official Analytical Chemists 60:546-562.

Rollag H. Degré M 1981 Effect of interferon preparations on the uptake of nonopsonized Escherichia coli by mouse peritoneal macrophages. Acta Pathologica et Microbiologica Scandinavica B 89:153-159.

Sansonetti P J, Hale T L, Dammin G J, Kapfer C, Collins H H, 
Formal S B 1983 Alterations in the pathogenicity of Escherichia coli K-12 after transfer of plasmid and chromosomal genes from Shigella flexneri. Infection and Immunity 39:1392-1402.

Sansonetti P J, Kopecko D J, Formal S B 1981 Shigella sonnei plasmids: evidence that a large plasmid is necessary for virulence. Infection and Immunity 34:75-83.
Strannegård Ø, Larsson I, Lundgren E, Miørner H, Persson H 1977 Modulation of immune responses in newborn and adult mice by interferon. Infection and Immunity 20:334 339.

Tyrrell D L J, Norrby E 1978 Structural polypeptides of measles virus. Journal of General Virology 39:219-229. 